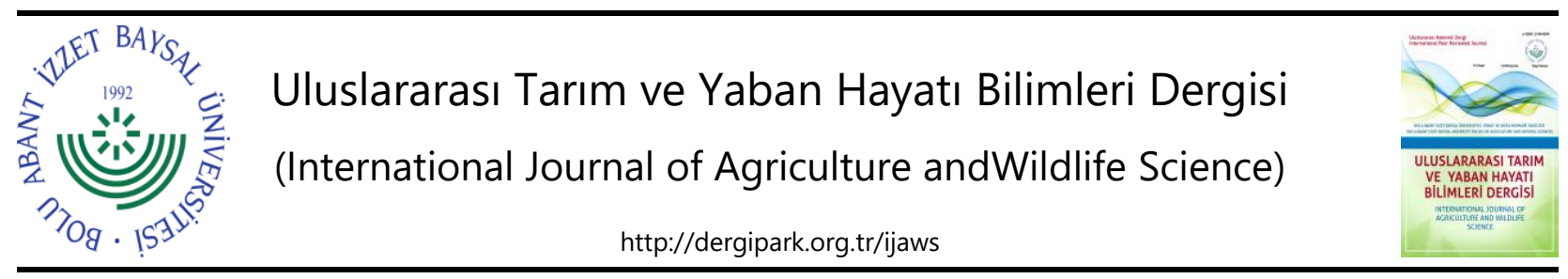

Araştırma Makalesi

\title{
Tokat ili Erbaa İlçesi Tarla Arazilerinde Kapitalizasyon Faiz Oranının Saptanması Üzerine Bir Araştırma**
}

\author{
Melek Yüksel (D)， Bilge Gözener ${ }^{*}$ (D) \\ Tokat Gaziosmanpaşa Üniversitesi Ziraat Fakültesi Tarım Ekonomisi Bölümü, Tokat \\ Geliş tarihi (Received): 23.02.2021～Kabul tarihi (Accepted): 25.05.2021
}

\begin{abstract}
Anahtar kelimeler:
Özet. Bu araştırmada Tokat ili Erbaa ilçesinde kuru şartlarda tarımsal üretim yapılan işletmelerin Tokat, kapitalizasyon faiz oranı, arazi rantı, arazi satış değeri sahip olduğu tarla arazilerine ilişkin kapitalizasyon faiz oranı hesaplanmıştır. Araştırmada kullanılan veriler, araştırma bölgesinde bulunan 92 adet tarım işletmesiyle yüz yüze görüşülerek yapılan anketlerden elde edilmiştir. Toplanan veriler 2018 yılı üretim dönemine aittir. İncelenen işletmelerin \%76.88'i mülk işletmeciliği şeklinde, \%23.12'si kiracılıkla işletilmekte olup ortakçlıkla işletilen arazilere rastlanmamıştır. İşletme arazilerinin tamamı ekilmekte olup nadas alanı bulunmamaktadır. İncelenen işletmelerde arazi varlığının \%60.42'si tarla arazisi, \%39.58'i bağ arazisinden oluşmaktadır. İncelenen işletmelerin gayrisafhasıla değeri $822.01 \mathrm{TL} \mathrm{da}^{-1}$ olarak bulunmuş, arazi rantının gayrisaf hasıla içindeki oranı \%32.18 olarak tespit edilmiştir. Araştırma sonucunda bölgede kullanılabilir kapitalizasyon faiz oranı, mülk işletmeciliği yapılan kuru tarla arazilerinde \%5.65 olarak hesaplanmıştır. Ayrıca araştırma kapsamında görüşülen üreticilerin tarımsal faaliyetlerine ilişkin bazı bilgiler elde edilmiştir. Hesaplanan kapitalizasyon faiz oranının güncel olması kamulaştırma gibi

durumlarda sağlıklı sonuç vermesi açısından önem taşımaktadır. Bu nedenle Türkiye'de her bölge ve il/ilçe için belirli aralıklarla ayrı ayrı hesaplamalar yapılabilir.

*Sorumlu yazar

bilge.gozener@gop.edu.tr
\end{abstract}

\section{A Research on Capitalization Interest Rate for Agricultural Fields of Erbaa Town of Tokat Province}

\section{Keywords:}

Tokat, capitalization interest rate, land rent, land sales value

\begin{abstract}
In this research, capitalization interest rates were calculated for dry farming lands of agricultural enterprises in Erbaa town of Tokat province were calculated. Research data were gathered through the face-to-face questionnaires made with 92 agricultural enterprises of the research region. The data gathered belong to the year 2018. Of the participant enterprises, $76.88 \%$ was operated as property enterprise, $23.12 \%$ was operated as tenancy enterprise and there were not any share cropping enterprises. All of the enterprise lands were cultivated and there were not any fallow lands. All of the farm lands are cultivated and there in no fallow land. In the enterprises examined, $60.42 \%$ of the land assets contsist of field land and $39.58 \%$ of vineyard land. The gross product value of the investigated enterprises was calculated as $822.01 \mathrm{TL} \mathrm{da}^{-1}$ and the ratio of land rent in gross product was calculated as $32.18 \%$. Available capitalization interest rate for dry-farming lands of property enterprises was calculated as $5.65 \%$. In addition some information about agricultural activities in the subjects encountered in the research reports were obtained. It is important that the calculated capitalization interest rate is up-to-date in terms of giving healthy results in cases such as expropriation. For this reason, separate calculations can be made at certain intervals for each region and province/district in Turkey.
\end{abstract}




\section{GíRiş}

Tarım toplumun büyük bir kesimine iş olanağı sağlaması, sanayiyi ham madde üretimi yoluyla desteklemesi, insan beslenmesinin temel kaynağı olması gibi nedenlerle Dünya'da ve Türkiye'de önemini korumaktadır (Onurlubaş ve Kızılaslan, 2007). Türkiye ekonomisinin gelişiminde tarımın payı önemli bir yere sahiptir. Tarımsal faaliyet yapılmasına uygun arazi miktarının arttııımaması, hatta bazı bölgelerde tarımın bilinçsiz olarak yapılması sonucu arazilerin verimini kaybetmesi söz konusu olmaktadır. Kente göç edenlerin artışı sonucunda teknoloji yetersizliği sebebiyle dekar başına sağlanan gelir, enflasyon oranında artmamaktadır. Arazi miktarının artırılmasının zor olması, sermaye yetersizliğinin tarımsal işletmeler için en önemli etkenlerden biri olması ve bunların yanı sıra arazi kıymetlerinin zaman içinde değişmesi kıymet takdirinin önemini artırmaktadır (Aydın, 2007). Tarımsal arazi miktarının artması güç olduğundan, artan nüfusun ihtiyaçlarını karşılayabilmek için üretimde birim alandan elde edilecek verimin artıııması gerekmektedir. Tarım topraklarının kıt kaynaklar arasında bulunması ise tarım arazilerinin değerlerinin giderek artmasına neden olmaktadır.

Değerleme bilimi arazi toplulaştırması, kıymet takdiri gibi birçok alanda kullanılmakta olup en yaygın kullanıldığı alan kamulaştırmadır. Kamulaştırma, taşınmazı kamulaştııılan mal sahibini, kamulaştırma yapan idareyi ve kamu hizmeti nedeniyle toplumun bir kesimini veya tüm toplumu etkileyen sosyal ve ekonomik boyutu olan idari bir işlemdir. Ekonomik ve sosyal gelişmeler ile hızlı kentleşme olgusu, devletin kamu yararı amacıyla pek çok alanda kamulaştırma yapmasını zorunlu kılmaktadır. Devlet, tarım dışı alanlarda olduğu gibi, tarım alanlarında da kamulaştırma yapmaktadır ve kamulaştırılan alanların büyük bölümünü tarım alanları oluşturmaktadır. Tarım alanlarında yapılan kamulaştırmalar, tarla arazilerini, sebze arazilerini, meyve bahçelerini, bağlık alanları ve zeytinlik alanları kapsayabilmektedir (Keskin, 2003). Kamulaştırma yapılmadan önce bölgenin kapitalizasyon faiz oranının ve bilimsel araştırmalarla belirlenen arazi gelirlerinin bilinmesi, kamulaştırma bedelinin daha gerçek verilerle ortaya konmasına yardımcı olmaktadır.

Türkiye'de her bölge için ayrı ayrı kapitalizasyon faiz oranı belirlenmemiştir. Yapılan çalışmalar genellikle yüksek lisans tezleri ve bilirkişi raporlarıdır. Akademik çalışmaların yetersizliği ile birlikte mevcut raporlar ve yargı kararları bilimsel sonuçlarla örtüşmemektedir. Bilimsel araştırmalar ile Yargıtay kararları arasındaki görüş farklılıklarının giderilebilmesi için kapitalizasyon faiz oranı ile ilgili çalışmaların artırılması gerekmektedir.

Arazi fiyat ve değerleri bölgeden bölgeye değişebildiği gibi, her bölgede fiyat ve değer üzerinde etkili olan faktörler de farklı olabilmektedir. Bu nedenle kapitalizasyon faiz oranlarını içeren araştırmaların her yöre için ayrı ayrı yapılması gerekmektedir.

Bu araştırmada Tokat ili Erbaa ilçesi kuru tarla arazilerinin değerinin belirlenmesinde kullanılacak kapitalizasyon faiz oranı hesaplanmıştır. Araştırmanın teorik ve uygulama yönünden; bilirkişiler, kıymet takdiri komisyonları ve yargı organları başta olmak üzere konu muhatabı kişi ve kuruluşlara faydalı ve yol gösterici olması beklenmektedir. Tokat ili Erbaa ilçesinde yapılması muhtemel kamulaştırma işlemlerinde bilimsel gerçeklik taşıyan arazi değerlerinin kullanılması, arazi sahiplerinin yaşayabileceği sorunları en aza indirebilecektir.

\section{MATERYAL VE METOT}

Bu araştırmada Tokat ili Erbaa ilçesine bağı 73 köyden tarla tarımının yoğun olarak yapıldığı 7 köy (Üzümlü, Karayaka, Ballıbağ, Yenimahalle, Koçak, Evyaba, Bağpınar), gayeli örnekleme yöntemiyle (\%10) belirlenmiştir. Belirlenen 7 köyde bulunan 1208 adet tarım işletmesi araştırmanın popülasyonunu oluşturmuştur. Araştırmanın ana materyalini popülasyonu temsil niteliğine sahip 92 adet tarım işletmesinden elde edilen 2018 yılı üretim dönemine ait orijinal veriler oluşturmaktadır.

Hesaplanan varyasyon katsayısı (\%50) popülasyonun homojen ve düzenli bir dağılıma sahip olduğunu göstermektedir. Örnek hacmin belirlenmesinde basit tesadüfi örnekleme yöntemi uygulanmıştır (Çiçek ve Erkan, 1996). Araştırmada örnek hacmi belirlenirken \%10 hata ve \%95 güven sınırlarında ( $t=1.96)$ çalışılış̧ıtır.

Araştırma bölgesinde yoğun olarak kuru koşullarda tarla tarımı yapıldığından kapitalizasyon faiz oranı sadece kuru tarla arazilerinde hesaplanmıştır. Bölgede ortakçılıkla işletilen tarla arazisi olmadığından bu tip işletmeler için kapitalizasyon faiz oranı hesaplanmamıştır.

Değer biçme yöntemleri sentetik ve analitik olmak üzere ikiye ayrılmakla birlikte tüm mallara aynı şekilde uygulanmayabilir. Bu araştırmada kapitalizasyon faiz oranının hesaplanması için gelirlerin kapitalizasyonu kriterinin yer aldığı analitik yöntem formülünden faydalanılmıştır.

$$
\text { Pazar değeri }(D)=\frac{\text { Arazinin yıllık net geliri }(\text { Rantl })(R)}{\text { Kapitalizasyon faiz oranı }(f)}
$$


Mülk işletmeciliği şeklinde işletilen arazilerin yoğun olduğu bölgelerde rant;

$$
R=G h-(M+\dot{\mathrm{I}} f+\dot{\mathrm{I}} \ddot{\mathrm{u}}+E \ddot{u}+V)
$$

formülüyle hesaplanmaktadır (Mülayim, 2001). Formülde;

R: Araziden elde edilen rant (yıllık ortalama net gelir), $G_{h}$ : Gayrisafi üretim değeri veya gayrisafi hasıla, M: İşletme dışından sağlanan hizmetlere ait masraflar (amortisman, sigorta, bakım vb.), İ İs: işletme (müstecir) sermayesi faiz karşılığı, Iü: İdare ücret karşılığı, Eü: El emeği (işgücü) ücret karşılığı, V: Işletme ile ilgili vergileri ifade etmektedir.

\section{BULGULAR VE TARTIŞMA}

Öncelikle işletmelerin sahip oldukları araziler ve bu arazilerin mülkiyet durumları incelenmiş ve bunlara dair veriler Çizelge 1'de sunulmuştur.

Çizelge 1. Incelenen işletmelerde tarla arazilerinin arazi kullanılış şekli ve üretim dalları itibariyle arazi büyüklükleri (da) ve oransal dağılımı (\%).

Table 1. The type of land use of the field lands in the enterprises examined and the size of the land in terms of production branches and its proportional distribution (\%).

\begin{tabular}{|c|c|c|c|c|c|c|c|c|c|}
\hline & \multicolumn{6}{|c|}{ İşletme Grupları } & \multicolumn{3}{|c|}{ Ortalama (92) } \\
\hline & \multicolumn{3}{|c|}{ 1. Grup (51) } & \multicolumn{3}{|c|}{ 2. Grup (41) } & & & \\
\hline & da & $\mathrm{K} * \%$ & $\mathrm{~T}^{* * \%} \%$ & da & $\mathrm{K} \%$ & $\mathrm{~T} \%$ & da & $\mathrm{K} \%$ & $\mathrm{~T} \%$ \\
\hline Mülk Tarla Arazisi & 11.67 & 100.00 & 69.10 & 43.15 & 100.00 & 73.08 & 25.70 & 100.00 & 71.95 \\
\hline Kira Tarla Arazisi & 5.22 & 100.00 & 30.90 & 15.90 & 100.00 & 26.92 & 9.98 & 100.00 & 28.05 \\
\hline Toplam & 16.89 & - & 100.00 & 59.05 & - & 100.00 & 35.68 & - & 100.00 \\
\hline
\end{tabular}

*K: Kendi içinde, ${ }^{* *} \mathrm{~T}$ : Toplam içinde.

Işletmelerin toplam tarla arazisi oranları iki işletme grubunda birbirine yakın bir görünümdedir. İşletmelerin genel ortalamasına bakıldığında \%71.95'inin mal sahipleri tarafından işletildiği görülmektedir. Kiracılıkla işletilen tarla arazilerinin oranı ise \%28.05 olarak belirlenmiştir.

Incelenen işletmelerde tarla ürünlerinin işletme grupları itibariyle ortalama üretim miktarları Çizelge 2'de gösterilmektedir.

Çizelge 2. Incelenen işletmelerde yetiştirilen tarla ürünlerinin ortalama üretim miktarları $(\mathrm{kg})$.

Table 2. Average production amounts of field crops grown in the enterprises examined (kg).

\begin{tabular}{|c|c|c|c|c|}
\hline & & \multicolumn{2}{|c|}{ İşletme Grupları } & \multirow[t]{2}{*}{ Ortalama (92) } \\
\hline & & 1. Grup (51) & 2. Grup (41) & \\
\hline & & $\mathrm{kg}$ & $\mathrm{kg}$ & $\mathrm{kg}$ \\
\hline \multirow{8}{*}{$\begin{array}{l}\text { Mülk tarla } \\
\text { arazisi }\end{array}$} & Tütün & 321.57 & 670.73 & 477.17 \\
\hline & Buğday & 1688.24 & 8414.63 & 4685.87 \\
\hline & Arpa & 107.84 & 1085.37 & 543.48 \\
\hline & Ayçiçeği & 664.71 & 1558.53 & 1063.04 \\
\hline & Fiğ & - & 117.07 & 52.17 \\
\hline & Bamya & 1.57 & 7.32 & 4.13 \\
\hline & Çavdar & - & 195.12 & 86.96 \\
\hline & Yonca & 227.45 & 829.27 & 495.65 \\
\hline \multirow{5}{*}{$\begin{array}{l}\text { Kira tarla } \\
\text { arazisi }\end{array}$} & Tütün & 411.76 & 48.78 & 250.00 \\
\hline & Buğday & 517.65 & 2329.27 & 1325.00 \\
\hline & Bamya & 1.37 & 2.44 & 1.85 \\
\hline & Ayçiçeği & 13.73 & 1421.95 & 641.30 \\
\hline & Arpa & 9.80 & 97.56 & 48.91 \\
\hline
\end{tabular}

İncelenen işletmelerde Çizelge 2'de görüldüğü üzere mülk tarla arazilerinde en yüksek üretim miktarına sahip olan ürün 4685.87 kg ile buğday olurken, ikinci sırada 1063.04 kg üretim miktarı ile ayçiçeği bulunmaktadır. Mal sahibi tarafından işletilen arazilerdeki üretim miktarları işletme grupları itibariyle göz önüne alındığında buğday üretim miktarında belirgin bir farklılık dikkat çekmektedir. Benzer durum kiracılıkla işletilen tarla arazilerinde de mevcuttur. Baştürk (2011) araştırmasında ürün gruplarının ekiliş alanlarını incelediğinde en yüksek orana sahip olan ürünün \%35.39 ile buğday olduğunu, Avcı (2010) \%32.80'lik oranla buğdayın, İncir (2015) \%33.71 ile 
buğdayın, Aydın (2007) \%74.90 ile ilk sırada buğdayın bulunduğunu belirtmişlerdir. Araştırma bölgesinde incelenen işletmelerde gayrisafi hasıla değeri Çizelge3'de verilmektedir.

Çizelge 3. Mal sahibi tarafından işletilen tarla arazilerinde gayrisaf hasıla ( $\left(\mathrm{TL} \mathrm{da}^{-1}\right)$.

Table 3. Gross income on farmland owned by the owner $\left(T L \mathrm{da}^{-1}\right)$.

\begin{tabular}{|c|c|c|c|c|c|c|c|c|c|}
\hline & Tütün & Buğday & Arpa & Ayçiçeği & Fiğ & Bamya & Çavdar & Yonca & Toplam \\
\hline Ekiliş alanı (da) & 3.10 & 12.57 & 2.10 & 6.33 & 0.32 & 0.09 & 0.16 & 1.03 & 25.7 \\
\hline $\operatorname{Verim}^{*}\left(\mathrm{~kg} \mathrm{da}^{-1}\right)$ & 142.00 & 230.00 & 175.00 & 200.00 & 90.00 & 400.00 & 299.00 & 1200.00 & - \\
\hline Toplam üretim $(\mathrm{kg})$ & 440.20 & 2891.10 & 367.50 & 1266.00 & 28.80 & 36.00 & 47.84 & 1236.00 & - \\
\hline Ortalama fiyat $\left(\mathrm{TL} \mathrm{kg}^{-1}\right)$ & 17.14 & 0.95 & 0.90 & 2.30 & 1.60 & 92.14 & 0.87 & 0.80 & - \\
\hline Ana ürün değeri (TL) & 7545.03 & 2746.55 & 330.75 & 2911.80 & 46.08 & 3317.04 & 41.62 & 988.80 & 17927.67 \\
\hline Yan ürün değeri (TL) & - & 2820.00 & 378.00 & - & - & - & - & - & 3198.00 \\
\hline Gayrisaf hasıla (Gh) & 7545.03 & 5566.55 & 708.75 & 2911.80 & 46.08 & 3317.04 & 41.62 & 988.80 & 21125.67 \\
\hline $\begin{array}{l}\text { Ürünlerin gayrisafi } \\
\text { hasıla içindeki payı (\%) }\end{array}$ & 35.71 & 26.35 & 3.35 & 13.78 & 0.22 & 15.71 & 0.20 & 4.68 & 100.00 \\
\hline Gayrisaf hasıla $\left(\mathrm{TLda}^{-1}\right)$ & 2433.89 & 442.84 & 337.50 & 460.00 & 144.00 & 36.86 & 260.13 & 960.00 & 822.01 \\
\hline
\end{tabular}

*Anonim, (2019).

Işletmelerin üretim desenine bakıldığında tütün, buğday, arpa, ayçiçeği, fiğ, bamya, çavdar, yonca gibi ürün gruplarının bulunduğu görülmektedir. Yapılan hesaplamalar sonucunda elde edilen verilere göre incelenen işletmelerdeki gayrisafi hasıla değeri 822.01TL da-10larak bulunmuştur. Ürünlerin gayrisafi hasıla içindeki payları incelendiğinde \%35.71 ile ilk sırada tütün bulunduğu gözlenmektedir. Tütünü \%26.35 ile buğday, \%15.71 ile bamya takip etmektedir.

Daha önce yapılmış olan araştırmalarda gayrisafi hasıla değeri; Avcı (2010) tarafından yapılan araştırmada 478.90 TL da-1 Incir (2015) tarafından yapılan araştırmada 475.74 TL da-1, Baştürk (2011) tarafından yapılan araştırmada $188.60 \mathrm{TL} \mathrm{da}^{-1}$, Aydın (2007) tarafından yapılan araştırmada $159.15 \mathrm{TL} \mathrm{da}^{-1}$ olarak hesaplanmıştır.

Rantın hesaplanabilmesi için gayrisafi hasıladan üretim masrafları değeri çıkarılmaktadır. İncelenen işletmelerde mal sahibi tarafından işletilen tarla arazilerinde üretim masrafları Çizelge 4'te sunulmaktadır.

Çizelge 4. Incelenen işletmelerde mal sahibi tarafından işletilen tarla arazilerinde üretim masrafları ( $\left(\mathrm{TL} \mathrm{da}^{-1}\right)$. Table 4. Production costs on farm lands operated by the owner in the enterprises surveyed $\left(T L \mathrm{da}^{-1}\right)$.

\begin{tabular}{|c|c|c|c|c|c|c|c|c|c|}
\hline & Tütün & Buğday & Arpa & Ayçiçeği & Fiğ & Bamya & Çavdar & Yonca & Toplam \\
\hline Ekiliş alanı (da) & 3.10 & 12.57 & 2.10 & 6.33 & 0.32 & 0.09 & 0.16 & 1.03 & 25.7 \\
\hline Tohum masrafı (TL) & 173.61 & 408.34 & 50.15 & 239.53 & 5.43 & 1.52 & 7.61 & 34.35 & 920.54 \\
\hline İlaç masrafı (TL) & 193.14 & 174.08 & 14.02 & 34.94 & 1.09 & 13.03 & 1.09 & 5.87 & 437.26 \\
\hline Gübre masrafı (TL) & 179.36 & 644.35 & 59.53 & 313.38 & - & 14.99 & - & 11.52 & 1233.13 \\
\hline Su ücreti (TL) & 17.98 & 3.84 & - & 8.81 & - & 13.03 & - & 16.85 & 60.51 \\
\hline Hasat Harman masrafı (TL) & 175.25 & 329.51 & 44.76 & 176.56 & - & 7.06 & - & 18.48 & 751.62 \\
\hline İp, çuval vb. masrafı (TL & 87.47 & - & - & - & - & 0.33 & - & - & 87.80 \\
\hline Taşıma masrafı (TL) & 11.81 & 1.91 & - & - & - & - & - & 1.09 & 14.81 \\
\hline Geçici işçi masrafı (TL) & 1190.11 & 3.84 & - & 5.93 & - & - & - & - & 1199.88 \\
\hline $\begin{array}{l}\text { İşletme Başına Toplam } \\
\text { Masraf (TL) }\end{array}$ & $n_{2028.73}$ & 1566.59 & 168.46 & 779.15 & 6.52 & 49.96 & 8.70 & 88.16 & 4696.27 \\
\hline $\begin{array}{l}\text { Toplam masraf } \\
\text { ürünlerin payı }(\%)\end{array}$ & $e_{43.20}$ & 33.36 & 3.59 & 16.59 & 0.14 & 1.06 & 0.18 & 1.88 & 100.00 \\
\hline
\end{tabular}

Çizelge incelendiğinde mal sahibi tarafından işletilen tarla arazilerinde üretim masraflarının parasal karşılığı toplamı 4 696.27 TL, dekara düşen masraf değeri 182.73 TL olarak hesaplanmıştır. Toplam masraf içerisinde üretilen ürünlerin payı incelendiğinde \%43.20 ile ilk sırada tütünün yer aldığı görülmektedir. Tütünü ise \%33.36 ile buğday takip etmektedir.

Işletmelerin üretim masrafları, sabit sermaye masrafları ve amortisman giderleri incelendiğinde toplam masrafların 304.26 TL da-1olduğu görülmektedir. Masrafların gayrisafi hasıla içindeki oranı ise \%52.73 olarak hesaplanmıştır (Çizelge 5). Aydın (2007), masrafların gayrisafi hasıla içindeki oranını sulu arazilerde \%37.74, kuru arazilerde \%49.69 olarak, Avcı (2010), masrafların gayrisafi hasıla içindeki oranını \%46.75, Baştürk (2011), masrafların gayrisafi hasıla içindeki oranını sulu arazilerde \%38.19, kuru arazilerde \%43.49 olarak, İncir (2015), masrafların gayrisafi hasıla içindeki oranını sulu arazilerde \%29.65, kuru arazilerde \%38.73 olarak hesaplamıştır.

İşletme sermayesine uygulanacak faiz oranının belirlenmesinde T.C. Ziraat Bankası'nın 2018 yılında sübvansiyonlu kredilere uygulanan tarımsal kredi faiz oranın yarısı olan \%4'lük oran kullanılmışır (Anonim 2018). 
Çizelge 5. İncelenen işletmelerde mülk tarla arazilerine ait masraflar (M) ( $\left(\mathrm{C} \mathrm{da}^{-1}\right)$.

Table 5. Costs of the property field lands in the enterprises examined (M) ( $\left.T L d a^{-1}\right)$.

\begin{tabular}{llc}
\hline & & Değer \\
\hline Sabit sermayelerin amortisman, tamir ve bakım & Motorlu makine ekipman değeri $\left(\mathrm{TL} \mathrm{da}^{-1}\right)$ & 80.05 \\
\cline { 2 - 3 } masrafları $\left(\right.$ TL da $^{-1}$ ) & Küçük alet ekipman değeri $\left(\mathrm{TL} \mathrm{da}^{-1}\right)$ & 41.48 \\
\hline Toplam sabit sermaye masrafları $\left(\mathrm{TL} \mathrm{da}^{-1}\right)$ & 121.53 \\
Toplam üretim masrafları $\left(\mathrm{TL} \mathrm{da}^{-1}\right)$ & 182.73 \\
Toplam masraflar (TL da-1) & 304.26 \\
Masrafların gayrisafi hasıla içindeki oranı (\%) & 52.73 \\
\hline
\end{tabular}

Incelenen işletmelerde işletme sermayesi olarak alet - makine, ambar mevcudu, para ve alacaklara rastlanmış ancak iş hayvanın sermayesine rastlanmamıştır. Çizelge $6^{\prime}$ da ortalama işletme sermayesi faiz karşıllığı sunulmaktadır.

Çizelge 6. Inncelenen işletmelerde belirlenen müstecir sermayesi faiz karşıllğı $\left(M_{f}\right)\left(T L d^{-1}\right)$.

Table 6. Interest provision for the subsidiary capital determined in the enterprises examined $\left(M_{f}\right)\left(T L d a^{-1}\right)$.

\begin{tabular}{ll}
\hline & Değer \\
\hline Alet makine varlığı & 33305.49 \\
Ambar mevcudu & 706.52 \\
Kasa mevcudu ve alacaklar & 2945.64 \\
Müstecir sermayesi toplamı & 36957.65 \\
Müstecir sermayesi faiz karşılığı (Mf) & 1478.31 \\
Müstecir sermayesi faiz karşı̆ı̆ı (TL/da) & 57.52 \\
Mf'ningayrisafi hasıla içindeki oranı (\%) & 7.00 \\
\hline
\end{tabular}

Elde edilen verilere göre müstecir sermayesi faiz karşılığı $57.52 \mathrm{TL}$ da-1olarak hesaplanmıştır. Müstecir sermayesi faiz karşıı̆ının gayrisafi hasıla içindeki oranı ise \%7.00 olarak belirlenmiştir. Daha önce yapılmış bazı araştırmalarda; Aydın (2007), müstecir sermayesi faiz karşıı̆ı̆ın gayrisafi hasıla içindeki oranını kuru tarla arazilerinde \%8.45, sulu tarla arazilerinde \%19.38 olarak, Avcl (2010), \%9.71 olarak, Baştürk (2011) kuru tarla arazilerinde \%5.96, sulu tarla arazilerinde \%7.82 olarak,Incir (2015) kuru tarla arazilerinde \%6.67, sulu tarla arazilerinde \%6.91 olarak hesaplamıştır.

Araşıırma kuru tarla arazileri üzerinden yapıldığı için idare ücret karşılığı hesaplanırken mal sahibi tarafından işletilen tarla arazilerinde gayrisafi hasılanın \%3'ü alınmıştır. İncelenen işletmelerde ortalama olarak belirlenen idare ücret karşılığı Çizelge 7'de gösterilmektedir.

Çizelge 7. Incelenen işletmelerde belirlenen idare ücret karşılığı (TL da-1).

Table 7. Administration fee determined in the enterprises examined $\left(T L \mathrm{da}^{-1}\right)$.

\begin{tabular}{ll}
\hline & Değer \\
\hline İdare ücret karşılığı (lü) & 24.67 \\
İdare ücret karşılığının gayrisafi hasıla içindeki oranı (\%) & 3 \\
\hline
\end{tabular}

Belirlenen gayrisafi hasıla değeri olan 822.01 TL'nin \%3'ü alınarak idare ücret karşıı̆ı hesaplanmış ve 24.67 TL olarak belirlenmiştir. Daha önce; İncir (2015) tarafından yapılan araştırmada idare ücret karşlığı kuru tarla arazilerinde $15.34 \mathrm{TL}$, sulu tarla arazilerinde $40.12 \mathrm{TL}$, Baştürk (2011) tarafından yapılan araştırmada kuru tarla arazilerinde $5.67 \mathrm{TL}$, sulu tarla arazilerinde $22.68 \mathrm{TL}$, Aydın (2007) tarafından yapılan araştırmada kuru tarla arazilerinde $4.77 \mathrm{TL}$, sulu tarla arazilerinde $10.05 \mathrm{TL}$, AvCı (2010) tarafından yapılan araştırmada32.55 TL olarak hesaplanmıştır.

Değeri biçilecek arazinin bulunduğu bölgede tarımsal faaliyetlerin yerine getirilmesi için yabancı işçi çalıştırma, işletmeci ve ailesinin çalışması veya hem işletmeci ve ailesi hem de yabancı işçiye ihtiyaç duyulabilir. Araştırma bölgesinde tüm üretim dalları için yabancı işgücüne gereksinim duyulmamaktadır. İ̧̧ücü ihtiyacı genellikle işletme içerisinden sağlanmaktadır. Anket çalışması esnasında elde edilen verilere göre incelenen bölgede tarımsal işlerde çalışan yabancı erkek işçilere ödenen ortalama günlük yevmiye $50 \mathrm{TL}$, kadın işçilere ödenen yevmiye ise $40 \mathrm{TL}$ olarak belirlenmiştir. Üretim dallarına ait işgücü istekleri, yöre için daha önce yapılmış bir çalışmadan yararlanılarak belirlenmiştir (Altıntaş, 2014). Belirlenen işgücü intiyaçları yabancı işçiye ödenen günlük ücret ile çarpılarak hesaplanmıştır. Incelenen bölgede belirlenen el emeği ücret karşılığı Çizelge 8'de verilmektedir. 
Çizelge 8. İncelenen işletmelerde belirlenen el emeği ücret karşılığı (Eü) ( $\left(T L\right.$ da $\left.^{-1}\right)$.

Table 8. Manual labor fee determined in the enterprises examined $\left(T L \mathrm{da}^{-1}\right)$.

\begin{tabular}{|c|c|c|c|c|c|c|}
\hline & $\begin{array}{l}\text { Ekiliş } \\
\text { alanı } \\
\text { (da) }\end{array}$ & $\begin{array}{l}\text { Dekara erkek } \\
\text { işgüicü birimi }\end{array}$ & $\begin{array}{l}\text { Toplam } \\
\text { işgücü } \\
\text { birimi (EiB) }\end{array}$ & $\begin{array}{l}\text { Ortalama } \\
\text { çalışılan gün } \\
\text { sayısı (Gün) }\end{array}$ & $\begin{array}{l}\text { Ortalama } \\
\text { Günlük ücret } \\
\left(\text { TLGün }{ }^{-1}\right)\end{array}$ & $\begin{array}{l}\text { El emeği ücret } \\
\text { karşılığı toplamı } \\
\text { (TL) }\end{array}$ \\
\hline Tütün & 3.10 & 170.23 & 527.71 & 52.77 & 50 & 2638.50 \\
\hline Buğday & 12.57 & 11.67 & 146.69 & 14.67 & 50 & 733.50 \\
\hline Arpa & 2.10 & 8.98 & 18.86 & 1.89 & 50 & 94.50 \\
\hline Ayçiçeği & 6.33 & 11.17 & 70.71 & 7.07 & 50 & 353.50 \\
\hline Fiğ & 0.32 & 6.60 & 2.11 & 0.21 & 50 & 10.50 \\
\hline Bamya & 0.09 & 753.11 & 67.78 & 6.78 & 50 & 339.00 \\
\hline Çavdar & 0.16 & 3.01 & 0.48 & 0.05 & 50 & 2.50 \\
\hline Yonca & 1.03 & 4.45 & 4.58 & 0.46 & 50 & 23.00 \\
\hline Toplam & 25.7 & 969.22 & 838.22 & 83.90 & & 4195.00 \\
\hline \multicolumn{6}{|c|}{ Dekara ortalama el emeği ücreti (Eü) } & 163.23 \\
\hline \multicolumn{6}{|c|}{ El emeği ücretinin gayrisafi hasıla içindeki oranı (\%) } & 19.85 \\
\hline
\end{tabular}

Incelenen işletmelerde dekara ortalama el emeği ücret karşılığı 163.23 TL olarak hesaplanmıştır. El emeği ücret karşılığının gayrisafi hasıla içindeki oranı ise \%19.85 olarak belirlenmiştir.

İncelenen işletmelerde arazi sermayesinden kaynaklanan vergi miktarları, köye ödenen köy salma ve koruma ücretleri bulunmaktadır. Çizelge 9'da ortalama vergi masrafları sunulmaktadır. İncelenen işletmelerde vergi masrafları dekara 7.77 TL olarak hesaplanmış ve vergi masraflarının gayrisafi hasıla içerisindeki payı ise \%0.95 olarak bulunmuştur.

Çizelge 9. İncelenen işletmelerde verilen vergi masrafı $(V)\left(\mathrm{TL} \mathrm{da}^{-1}\right)$.

Table 9. Tax charge (V) given in the enterprises examined ( $\left.T L \mathrm{da}^{-1}\right)$.

\begin{tabular}{ll}
\hline & Değer \\
\hline Vergi masrafları (V) & 7.77 \\
Vergi masraflarının Gh içindeki oranı (\%) & 0.95 \\
\hline
\end{tabular}

Daha önce yapılmış bazı araştırmalarda gayrisafi hasıla içindeki vergi oranı; Aydın (2007) tarafından kuru tarla arazilerinde \%1.27, sulu tarla arazilerinde \%0.76 olarak, Avcı (2010) tarafından \%0.75 olarak, Baştürk (2011) tarafından kuru tarla arazilerinde \%0.66, sulu tarla arazilerinde \%0.35, Incir (2015) tarafından kuru tarla arazilerinde $\% 0.19$, sulu tarla arazilerinde $\% 0.88$ olarak hesaplanmışıır.

Gayrisafi hasıladan arazi kirası ve arazi sermayesinin faiz karşılığı hariç işletmecinin el emeği işgücü, yabancı işgücü, idare ücret karşılığı olarak ayrılan masraflar düşüldükten sonra elde edilen net gelire rant adı verilir (Cinemre, 1992).

Araştırma bölgesindeki tarım işletmelerinin geneline bakıldığında arazi rantının, arazi türü ve arazideki işletmeci başarılarına göre değişiklik gösterdiği görülmektedir. Arazi rantını etkileyen faktörlere ise arazinin verimliliği, yola yakınlığı, köye veya kente olan uzaklığı, uygulanan münavebe sistemi, arazinin topografik yapısı, büyüklüğü, parselasyon durumu ve sulanabilme imkanı örnek verilebilir (Mülayim, 2001).

Araştırmada incelenen tüm masraf unsurları belirlenen gayrisafi hasıladan (Gh) çıkarılarak arazi rantına ulaşılmıştır. İncelenen işletmelere ait ortalama arazi rantı Çizelge $10^{\prime}$ da sunulmaktadır.

Araştırma bölgesinde mal sahibi tarafından işletilen arazilerin ortalama rantı $264.56 \mathrm{TL}$ olarak hesaplanmıştır. Arazi rantının, gayrisafi hasıla içindeki payının \%32.18 olduğu gözlenmektedir. Daha önce yapılmış araştırmalarda arazi rantının gayrisafi hasıla içindeki payı; Aydın (2007) kuru tarla arazilerinde \%25.63, sulu tarla arazilerinde \%37.03, Avcı (2010), \%24.76, Baştürk (2011) kuru tarla arazilerinde \%44.93, sulu tarla arazilerinde \%33.49, Incir (2015) kuru tarla arazilerinde \%41.39, sulu tarla arazilerinde \%40.97 şeklinde hesaplanmıştır.

Arazi piyasasında bir pazar değeri elde edebilmek için uzun bir araştırma ve inceleme dönemi gerekmektedir. Arazilerin anında alıcı bulma ve satılma durumu olmadığından diğer piyasa yapılarından farklı bir konumdadır. Araziye değer biçme gelirlerin kapitalizasyonu yöntemiyle yapıldığında, gelecekte elde edilebilecek gelirler fiyat belirlemede önemli yer tutar.

Incelenen işletmelerde mal sahibi tarafından işletilen kuru tarla arazilerinin ortalama satış değeri $4683.22 \mathrm{TL}$ $\mathrm{da}^{-1}$ olarak hesaplanmıştır. Arazi değerleri köye ve yola uzaklık, parçalıık durumu gibi faktörlere göre değişkenlik göstermektedir. 
Çizelge 10. Incelenen işletmelerde ortalama arazi rantı $\left(\mathrm{TL} \mathrm{da}^{-1}\right)$.

Table 10. Average land rent in the enterprises surveyed $\left(T L \mathrm{da}^{-1}\right)$.

\begin{tabular}{ll}
\hline Gayrisafi Hasıla (Gh) & 822.01 \\
Masraflar (M) & 304.26 \\
Müstecir (İşletme) Sermayesi Faizi (Mf) & 57.52 \\
İdare Ücret Karşılığı (lü) & 24.67 \\
El Emeği Ücret Karşılığı (Eü) & 163.23 \\
Vergiler (V) & 7.77 \\
Arazi Rantı (R) & 264.56 \\
Arazi Rantının Gayrisafi Hasıla İçindeki Oranı (\%) & 32.18 \\
\hline
\end{tabular}

Bu çalışmada araştırma bölgesi olan Tokat ili Erbaa ilçesinde ortakçılıkla ve kiracılıkla işletilen tarım arazisi oranının düşük, tarımın ise kuru arazi koşullarında yapılması nedeniyle yalnızca kuru şartlarda tarım yapılan mülk tarla arazileri için kapitalizasyon faiz oranı hesaplanmıştır.

Mülk işletmeciliği şeklinde işletilen kuru şartlarda tarım yapılan tarla arazilerinde rant ve satış değerleri dikkate alınarak bulunan kapitalizasyon faiz oranı:

$$
\mathrm{f}=\frac{\sum \mathrm{R}}{\sum \mathrm{D}}=\frac{264.56}{4683.22}=\% 5.65 \text { olarak hesaplanmıştır. }
$$

Yörede yapılacak değer biçme çalışmalarında bu değerin arazinin durumuna göre \%1 oranında artııııp azaltılması uygun olabilmektedir. Daha önce yapılmış araştırmalarda kapitalizasyon faiz oranlarından bazıları aşağıda verilmiştir;

İncir (2015), Tokat ili Çevreli Beldesi kuru tarla arazilerinde \%4.30, sulu tarla arazilerinde \%4.76, Baştürk (2011), Samsun ili Ladik ilçesi kuru tarla arazilerinde \%4.38, sulu tarla arazilerinde \%5.06, Aydın (2007), Tokat ili Zile ilçesi kuru tarla arazilerinde \%3.06, sulu tarla arazilerinde \%5.17, Gündoğmuş ve Taşçı (2017), Denizli ili Çivril ilçesi kuru tarla arazilerinde \%5.83, sulu tarla arazilerinde \%5.03, Oğuz ve Ünal (2004) Konya ili Çumra ilçesi sulu tarla arazilerinde \%5.20, Engindeniz (2001), İzmir ili Beydağ Barajı bölgesinde \%4.48, Karakayacı ve Oğuz (2006), Konya ili Ereğli ilçesi tarım arazilerinde \%6.20, Avcı (2010), Tokat ili Pazar ilçesi tarla arazilerinde \%4.38 olarak hesaplamıştır.

\section{SONUÇ}

Tokat ili Erbaa ilçesinde yapılan araştırmada kuru mülk arazilerde kullanılabilir ortalama kapitalizasyon faiz oranı \%5.65olarak bulunmuştur. Araştırmanın amacı olan kapitalizasyon faiz oranının tespitinde gerekli olan unsurlar özetlendiğinde;

İncelenen işletmelerde gayrisafi hasıla değeri $822.01 \mathrm{TL} \mathrm{da}^{-1}$ olarak tespit edilmiştir. Mal sahibi tarafından işletilen tarla arazilerinde toplam üretim masraflarının parasal karşılı̆ı ise 182.73TL olarak bulunmuştur. Amortisman ve tamir-bakım masraflarının oluşturduğu sabit sermaye masrafları ise 121.53 TL olarak hesaplanmakla birlikte dekara düşen toplam masraf $304.26 \mathrm{TL}$ olarak bulunmuştur. İşletmelerin müstecir sermayesi faiz karşıığı $57.52 \mathrm{TL} \mathrm{da}^{-1}$, idare ücret karşılığı $24.67 \mathrm{TL}_{\text {da }}{ }^{-1}$, el emeği ücret karşılığı $163.23 \mathrm{TL} \mathrm{da}^{-1}$, ortalama vergi masrafları ise $7.77 \mathrm{TL} \mathrm{da}^{-1}$ olarak tespit edilmiştir.

Elde edilen veriler kullanılarak hesaplanan arazi rantı $264.56 \mathrm{TL} \mathrm{da}^{-1}$ olarak belirlenmiştir. Arazi rantının gayrisafi hasıla içindeki payı ise \%32.18olarak hesaplanmıştır. Araştırma kapsamında belirlenen ortalama arazi satış değeri 4 683.22 TL da-1olarak tespit edilmiştir. Belirlenen bulgulardan hareketle kapitalizasyon faiz oranı araştırma bölgesi için \%5.65 olarak hesaplanmıştır.

Tokat ili Erbaa ilçesi için yapılan araştırma kapsamında elde edilen bulgular değerlendirildiğinde, kapitalizasyon faiz oranının Türkiye'de her bölge ve il/ilçe için belirli aralıklarla ayrı ayrı hesaplanması gerektiği söylenebilir. Bunun nedeni kapitalizasyon faiz oranının ve bu oranı etkileyen faktörlerin her bölgede farklı olmasıdır. Aynı ilçenin farklı bölgelerinde bile, değişen arazi yapısı veya diğer faktörler sebebiyle farklı kapitalizasyon faiz oranları hesaplanabilir. Hesaplanan kapitalizasyon faiz oranının güncelliğini koruyor olması kamulaştırma gibi durumlarda daha sağlıkı sonuçlara ulaşılması açısından önem taşımaktadır. Araştırma bölgesine katkı sağlayacak teknolojik gelişmeler, altyapı yatıımları, bölgenin sosyal konumunu etkileyecek olumlu veya olumsuz değişimler yaşanması kapitalizasyon faiz oranını değiştirebilmektedir. Elde edilen kapitalizasyon faiz oranı sayesinde bölgede yapılacak olan kıymet takdiri çalışmaları için kullanılabilir veriler sağlanmaktadır. 


\section{ÇIKAR ÇATIŞMASI}

Yazarlar arasında herhangi bir çıkar çatışması bulunmamaktadır.

\section{YAZAR KATKISI}

MY: Anketlerin yapılması, verilerin programa aktarımı, analizlerinin gerçekleştirilmesi ve makalenin yazılması BG: Analizlerin değerlendirilmesi, makalenin dizaynı ve makalenin yazılması

\section{KAYNAKLAR}

Altıntaş, G. (2014). Tokat, Amasya, Yozgat ve Sivas Yörelerinde Yetişstirilen Bazı Tarım Ürünlerinin 2013 Yılı Üretim Girdileri ve Maliyetleri. Tarım ve Orman Bakanlığı Tarımsal Araştırmalar ve Politikalar Genel Müdürlüğü Orta Karadeniz Geçit Kuşağı Tarımsal Araştırma İstasyonu Müdürlüğü. Enstitü Yayın No: 261-P23.

Anonim, (2018). 2018 yllı sübvansiyonlu tarımsal kredi faiz oranları. http://www.furkanlardanismanlik.com/index.php/destekler/suebvansiyonlu-krediler/2889-2018-yili-\%C3\%BCbvansiyonlutarimsal-kredi-faiz-oranlari.html-. Erişim Tarihi: 25 Ekim 2018.

Anonim, (2019). Tokat Valiliği Tarım ve Orman ilı Müdürlüğü, Bazı tarım ürünlerinin maliyetleri ve ağaç değerleri. Erişim Tarihi: 12 Nisan 2019.

Avcı, İ. (2010). Tokat ili Pazar ilçesi tarla arazilerinde kapitalizasyon oranı tespiti üzerine bir araştırma. Yüksek Lisans Tezi, Gaziosmanpaşa Üniversitesi, Fen Bilimleri Enstitüsü, Tokat.

Aydın, H. (2007). Zile Ovası tarla arazilerinde kapitalizasyon oranının tespiti üzerine bir araştırma. Yüksek Lisans Tezi, Gaziosmanpaşa Üniversitesi, Fen Bilimleri Enstitüsü, Tokat.

Baştürk, A.(2011). Samsun ili Ladik ilçesi tarla arazilerinde kapitalizasyon oranının saptanması üzerine bir araştırma. Yüksek Lisans Tezi, Gaziosmanpaşa Üniversitesi, Fen Bilimleri Enstitüsü, Tokat.

Cinemre, H. A. (1992). Tarım arazisi kıymet takdiri kavramlar, metotlar, problemler ve çözüm yolları. Kooperatifçilik Dergisi, 95, Ankara.

Çiçek, A., \& Erkan, O. (1996). Tarım ekonomisinde araştırma ve örnekleme yöntemleri, Gaziosmanpaşa Üniversitesi Ziraat Fakültesi Yayını, Tokat.

Engindeniz, S. (2001). Beydağ Barajı göl alanında kalan tarım arazilerinin kamulaştııımasında kullanılabilecek kapitalizasyon faiz oranının saptanması üzerine bir araştırma, Ege Üniversitesi Ziraat Fakültesi Dergisi, 38 (2-3), 95-102.

Gündoğmuş, M. E., \& Taşçı, M. (2017). Hünnap (Zizyphus jujube Mill.) bahçelerinde gelir yöntemine göre değerleme: Denizli ili Çivril ilçesi örneği. Tekirdağ Ziraat Fakültesi Dergisi, 14, 42-53.

Incir, S. (2015). Tokat ili Çevreli Beldesi tarla arazilerinde kapitalizasyon faiz oranının saptanması üzerine bir araştırma. Yüksek Lisans Tezi, Gaziosmanpaşa Üniversitesi, Fen Bilimleri Enstitüsü, Tokat.

Karakayacı, Z., \& Oğuz, C. (2006). Konya ili Ereğli ilçesi tarım arazileri için kapitalizasyon oranının tespiti. Selçuk Üniversitesi Ziraat Fakültesi Dergisi, 20(40), 21-26.

Keskin, G. (2003). Tarım arazilerinin kamulaştııılmasında değer biçme: Akyar Barajı örneği. Akdeniz iktisadi ve Idari Bilimler Fakültesi Dergisi, (5), 91-107.

Mülayim, Z. G. (2001). Tarımsal Değer Biçme ve Bilirkişilik, Yetkin Yayınları, Ankara.

Oğuz, C. \& Ünal, Z. (2004). Konya ili Çumra ilçesi sulu tarım arazilerinde kapitalizasyon faiz oranının tespiti. Selçuk Üniversitesi Ziraat Fakültesi Dergisi, 18(33), 8-16.

Onurlubaş, H. E., \& Kızılaslan, H. (2007). Türkiye'de Bitkisel Yağ Sanayindeki Gelişmeler ve Geleceğe Yönelik Beklentiler. Tarımsal Ekonomi Araştırma Enstitüsü (TEAE), Yayın No: 157, Ankara. 